\title{
"The only way we knew how:" provenancial fabulation in archives of feminist materials
}

\author{
Jessica M. Lapp ${ }^{1,2}$ (D)
}

Accepted: 20 October 2021 / Published online: 9 November 2021

(c) The Author(s), under exclusive licence to Springer Nature B.V. 2021

\begin{abstract}
Although much has been written on the archival principle of provenance and the centrality of records creation to archival practices and processes, there has been little exploration of how records creation is figured and enacted across specific archival sites and spaces. This article centers records creation in two digital archives of feminist materials: Alternative Toronto and Rise Up! Feminist Digital Archive with the aim of demonstrating records creation as an imaginative and fabulatory process of meaning-making. By decentering the notion of a singular, remarkable creator in favor of a multiplicity of creating contexts and actors, Rise Up! and Alternative Toronto enable imaginative acts of records creation that play with the spatial and temporal boundaries of records, pushing them into new, oftentimes unanticipated relationships to other records, users, and intervenors. In this article, I propose that provenancial fabulation can be characterized through four dimensions: first, it plays with contradictory records contexts putting them in conversation with one another; second, it troubles the order and organization of the past; third, it extends the temporal and spatial boundaries of historical records and accounts; and fourth, it acts infrastructurally to circulate ideas, imaginaries, narratives, and relationalities. In creating and configuring digital records according to feminist understandings of archival value and historical continuity, Alternative Toronto and Rise Up! demonstrate provenancial fabulation as a structuring force in the circulation of feminist knowledges and desires.
\end{abstract}

Keywords Provenance $\cdot$ Fabulation $\cdot$ Records creation · Feminist archives · Imagination $\cdot$ Intra-action $\cdot$ Digital records

Jessica M. Lapp

jessica.lapp@utoronto.ca

1 Faculty of Information, University of Toronto, 140 St. George St., Toronto, ON M5S 3G6, Canada

2 Toronto, Canada 


\section{Introduction}

Exploring the concept of records creation within archival collections of feminist materials is a complex undertaking. Simultaneously pushing against archival convention by disrupting the heteropatriarchal values that many archives have been built around, and replicating many of the power structures that have formed to marginalize and obscure difference, feminist archival practice is never unified or beyond reproach. The intent of this piece is not to parse and define different forms of feminism or feminist archiving projects, but rather, to understand feminism as a critical practice, one that acts "as an intersectional political philosophy committed to the dismantling of heteronormative, capitalist, racist patriarchy" (Cifor and Wood 2017 , p. 2). In this figuring, feminism is understood as "a tool for coalitional work around overlapping and interconnecting political realities" (p. 2). ${ }^{1}$ Feminist archival formations, like all archives, are bounded: they are "constructed windows into personal and collective processes. They at once express and are instruments of prevailing relations of power" (Harris 2002, p. 63). It is how those boundaries are drawn, negotiated, envisioned, pushed, and enacted that matter for feminist archiving projects. The process is as political as the materials themselves, sometimes, even more so. Inevitably decisions are made that frame feminism within the politics of the group or organization doing the archiving; the archival practice often reflects the political practice - although there are always exceptions to the rule. Anchoring any understanding of the political and social power enacted through archives of feminist materials is the role they play as sites of both evidence and memory, evidence of past struggle, and memory of events, relationships, and moments in time. Although sometimes depicted as the "central competing dichotomy in mythologies of the archival profession," memory and evidence exist in powerful synergy (Cook 2013, p. 100). Indeed, from cat shows to protest marches, archives of feminist materials open a multitude of avenues to the past.

Despite the archival field's tendency to extol the virtues of an expanded understanding of archival creation, discussions surrounding the nature of provenance and records creation lack a nuance and precision that "belies the depth of the discussion that has occurred regarding creatorship in the archival literature" (Douglas 2018, p. 31). Jennifer Douglas (2018, p. 45) suggests "while there has been high-level, theoretical discussion about the need to expand the principle of provenance in the archival literature, there has been little empirical research that directly shows how archives - personal or organizational - are created over time". Responding to Douglas' call for more nuanced and in-depth explorations of records creation, this article aims to provide an elaborated framework for understanding records creation in archives of feminist materials through the concept of provenancial fabulation. Provenancial fabulation contends with the continual acts of records creation occurring

\footnotetext{
1 For further analysis of how feminist praxis has influenced, shaped, and challenged archival practice, see Cifor and Wood (2017) "Critical Feminism in the Archive"; Caswell and Cifor (2016) "From Human Rights to Feminist Ethics: Radical Empathy in the Archive"; and Caswell (2019) "Dusting for Fingerprints: Introducing Feminist Standpoint Appraisal."
} 
in archives of feminist materials and situates them within a continuum of feminist knowledge generation using Karen Barad's (2007) concept of "intra-action." Intraaction suggests that practices of knowing materialize the world in distinct ways, providing openings for considering how feminist knowledge practices shape records context and histories. The intra-active nature of feminist records creation enables an imaginative and speculative approach to archival provenance, one that reflects the call for fabulatory approaches to history and narrative building issued by Saidiya Hartman (2008, 2019), Donna Haraway (1988), Heather Love (2007) and Adrienne Rich (1979), and addresses the role of the archival imaginary in shaping records and their communities of use as articulated by Caswell (2014a), Caswell and Gilliland (2015), Gilliland and Caswell (2016), and Brilmyer et al. (2019). As a concept, provenancial fabulation holds these intellectual threads in tension with one another, presenting a feminist figuring of provenance that attends to the distributed and mutable nature of records creation.

For the purposes of this article, provenancial fabulation is explored within the context of two Toronto-based digital archives: Rise Up! Feminist Digital Archive a digital archive documenting Canadian feminist organizing between 1970 and 1990, and Alternative Toronto a digital community archive documenting Toronto's alternative scenes between 1980 and 1999 (Radovac 2018; Rise Up! N.D.). Both archives take a post-custodial approach to archiving activism-physical records remain with donors while their digital surrogates are made available online-and both archives are collectively run and operated by community members, academics, and activists. In researching processes of records creation within the context of feminist archiving projects, I conducted a series of semi-structured interviews with the Rise Up! organizing collective and with Lilian Radovac, the lead organizer of Alternative Toronto. From 2018 to 2019, I also worked with Alternative Toronto as a research assistant and acted as a member of the advisory collective for Rise Up! The interview excerpts and descriptions of the archives used in this article are the result of time spent working with, and talking to, folks involved in both archiving projects. This research was fundamentally shaped by my dual researcher-participant role, and by my own positionality as a queer, white, cisgender woman and feminist archival scholar.

In the midst of talking through the process of archiving feminist materials for Rise Up!, collective member Tara Cleveland remarks: “[We] aren't archivists. We never were ... we approached everything from a feminist perspective because that's the only way we knew how to do it...doing things as a collective and not a hierarchy, having everyone involved in deciding our strategies, our future, what we're trying to do." The Rise Up! collective of historians, activists, educators, and artists are decidedly archivists, even though they may not immediately identify as such. In identifying, preserving, and making accessible the ephemera and publications of mid-twentieth century feminist struggle through their digital archive, the Rise Up! archive is undertaking work familiar to many in the archival profession. Although "archiving" may not explicitly exist as part of their repertoire of resistance, certainly historicizing, remembering, and sharing knowledge and information does; for these archival organizers their archival efforts exists within a continuum of information activism (McKinney 2020). 
A few blocks Northwest of the Annex-based home where Rise Up! members reflected on their ongoing archival practice, Lilian Radovac and I settle into a conversation about the role of community-based digital archives for those whose lives and experiences are not represented in institutional archival organizations. Radovac, the lead organizer of Alternative Toronto, began the project out of a dissatisfaction with how the Toronto activism of her youth was represented through existing historical records and accounts (Radovac 2018). Sitting on Radovac's balcony overlooking the train tracks carrying commuters to the outer East and West corners of Toronto, we talk about her hopes for Alternative Toronto, and its ability to shape counter narratives of local activism through a focus on digitizing political and artistic cultural production.

For both of these digital archiving projects, Rise Up! and Alternative Toronto, the attribution of a record's context - its history of creation and its order within a larger aggregation of records - is a central means of establishing the record as evidence and memory of feminist struggle. ${ }^{2}$ The establishment of records order and origins does more than track custodial history or establish clear contexts of creation; rather, the attribution of records order and origins is central to establishing feminist and queer life worlds; it is a feminist world-building practice. It is this ever-shifting, contingent, messy system of records creation and context that provenancial fabulation contends with. Provenancial fabulation enables a thinking through of how archives of feminist materials envision records origins and order, and how they enact records origins and order through arrangement and descriptive practices. In proposing provenancial fabulation as a feminist understanding of records creation, I suggest that it can be characterized in the following ways: first, it plays with contradictory record contexts putting them in conversation with one another; second, it troubles the order and organization of the past to "imagine what cannot be verified" or what could be (Hartman 2008, p. 13); third, it extends the temporal and spatial boundaries of historical records and accounts; and fourth, it acts infrastructurally to circulate ideas, narratives, and relationalities. In undertaking this imaginative archival attribution process, provenancial fabulation has the ability to actively decenter "the archival gaze"-by which I mean the Western archival tradition predicated on singular, central creator bodies - to instead account for difference, contention, and the entangled nature of feminist lives and histories.

\footnotetext{
${ }^{2}$ Although Alternative Toronto does not explicitly define itself as a 'feminist archive,' it is oriented around trans feminist and queer anti-oppression practices and processes. The archive "focus[es] on local resistance cultures in politics and the arts that were rooted in radical, grassroots and do-it-yourself movements" with an eye to how documentary practices have historically "privileged cisgender, heteronormative, white, abled, middle-class narratives" (Alternative Toronto 2021).
} 


\section{Thinking intra-actively}

In her article "A Call to Rethink Archival Creation" (2018) Jennifer Douglas asks: "What does it mean to create a record? To be a record creator?" My research into records creation in archives of feminist materials responds to Douglas' assertion that more critical inquiry should be directed towards identifying and understanding records creation and its iterations across diverse archival settings. Douglas' work identifying acts of records creation in the archives of writers demonstrates the range of archival interlopers involved in building records context and meaning; she establishes that a greater understanding of intervening forces opens up myriad through-lines, avenues, and windows for records interpretation and activation. In the two digital archives I introduce here, records creation has taken many forms. Like Douglas, I do not make any claims to an exhaustive examination of records creation; rather, I hope that this scholarship demonstrates how feminist processes, practices, values, knowledges, histories, and methods shape records in powerful and evocative ways. In taking up Douglas' provocation I extend her line of inquiry asking: What do digital records of feminist organizing and their circulation signify? What are there worldmaking abilities? To explore these questions, I turn to Karen Barad's diffractive methodology (2007, 2014).

Barad suggests that "a diffractive methodology is a critical practice for making a difference in the world. It is a commitment to understanding which differences matter, how they matter, and for whom. It is a critical practice of engagement, not a distance-learning practice of reflecting from afar" (2007, p. 90). Barad's methodology employs a feminist material-discursive framework that centers the importance of reading insights through one another, and attending to how "the world is materialized differently through different practices" (p. 89). Barad emphasizes the importance of recognizing how knowledge is generated and circulated suggesting "...the point is not merely that knowledge practices have material consequences but that practices of knowing are specific material engagements that participate in (re)configuring the world" (p. 91). In exploring the concept of provenancial fabulation, I demonstrate how practices of knowing contribute both materially and discursively in the construction of records and those parts of the world they stand in for.

With its world-building qualities, archival creation itself can be considered a diffraction apparatus: a "technolog[y] that make[s] part of the world intelligible to another part of the world in specific ways, by means of intra-actions between human and non-human agencies and objects of observation" (Calderon-Sandoval and Sanchez-Espinosa 2019, p. 1). Here I draw from Calderon-Sandoval and Sanchez-Espinosa's (2019) work positioning feminist documentary cinema as diffraction apparatuses to suggest that the processes of creation in archives of feminist material can be understood in similar terms. The field of feminist documentary studies offers some generative and constructive parallels to the field of archival studies and the processes of archival creation that render "parts of the world intelligible" to other parts of the world; both are concerned with how feminist consciousness is constructed, produced, reproduced, distributed, and made 
available to wider publics, and both are concerned with how difference is represented, elaborated on, and constrained by, the documentary media form (p. 5).

To consider archival creation as a diffraction apparatus is to understand that creation as an act, and as a set of intentions, creates a system of legibility that renders some voices, experiences, and archival formations visible and obscures others. It does this through what Barad terms "intra-actions" between human actors, knowledge systems, material conditions, and archival records themselves. As opposed to the word "interaction" which assumes a set of distinct actors with pre-determined agencies that come together in exchange, "the notion of intra-action recognizes that distinct agencies do not precede, but rather emerge through, their intra-action" (Barad 2007, p. 33). Diffractive methodology may be dense with complexity and neologisms; however, it provides a meaningful contribution to thinking about how archives attend to relations of difference (or not) and how a feminist material-discursive reading of records creation can explicate how different archival formations enable and constrain particular sets of relations and ways of understanding and being in the world; it is a methodology that centers the "vision" question in feminist theory. After all, Barad's conceptualization of diffraction draws from the domain of physics, where diffraction is literally a way of seeing. As Donna Haraway (1992, p. 300) notes, "diffraction does not produce 'the same' displaced, as reflection and refraction do. Diffraction is a mapping of interference, not of replication, reflection, or reproduction." Not coincidentally, vision-what we see, how we see, the ways in which the world is diffracted and represented through documentation, narrative, and storytelling - is central to the work of many feminist thinkers across a range of disciplines including Rich (1979), Haraway (1988), Hooks (1989), Butler (1997), Love (2007), Hartman (2008, 2019) and Browne (2015), all of whom interrogate why the "view from nowhere" approach, the objective seer, perpetuates and sustains heteropatriarchal, classed, and raced hierarchies of power. A concern with the power of " 'scopic regimes' and their relationship to gender inequality and oppression" has been extended to the heritage domain as well, where they are interrogated for their ability to normalize practices of collecting and interpretation that create "binaries laden with value judgments of superiority and inferiority" (Clover and Williamson 2019, p. 145-146). Haraway suggests that "optical instruments are subject-shifters" (1992, p. 295), and no one knows this better than those who have been rendered unwilling subjects, or not rendered at all, through the optical instruments deployed in the service of sustaining and enacting hegemonic power.

Archival creatorship has historically coalesced around, and been legitimated by, the same systems of power that rendered archives-themselves powerful optical instruments with their own ability to render and obscure-white, patriarchal, and stratified by class. Singular creators were centered and amplified in part because they were historically white powerful men, and in part because recognizing creatorship as existing outside this paradigm threatened its supremacy (Yeo 2009; Drake 2016; Lapp 2019). Understanding records creation as a diffraction apparatus, with the potential to center difference, means thinking through records creation as a technology that makes parts of the world legible through the intra-action of many bodies, sites, times, and objects. This understanding of record's creation does not suggest that all forms of creatorship exert the same force on a record, but it does 
recognize that creatorship encompasses many sites and many actors. It refutes the idea of a stable and immutable creator in favor of increasingly interpolated and complex understandings of a record's use and context.

\section{A brief history of provenance}

Over the past twenty years, provenance, as a system of records origins and order, has been critiqued for its inability to account for the complexity and collectivity of records creation. Grappling with the reality of distributed contexts of creation, multiple creator forces, and evolving rosters of records intervenors and interlocuters, archival scholars have introduced a range of language and frameworks for understanding the limitations and potential of provenance (Hurley 2005; Bastian 2006; MacNeil 2008; Caswell 2014b; Wood et al. 2014; Drake 2016; Douglas 2017, 2018; Brilmyer 2020). As a system of attribution, provenance has been guiding archival arrangement and descriptive practices in the West for over 200 years (Drake 2016). As Jarrett Drake writes: "[provenance] is the central organizing unit for description in most archival repositories and archivists must come to terms with the ways in which we incorporate the privilege, power, and patriarchy of provenance into our everyday practices" (2016). In what follows, I outline a brief history of provenance in an effort to critique and explicate provenance's inability to account for feminist records creation.

In Western archival theory and practice, provenance is often considered both the historical and scholarly starting point (Eastwood 1994, p. 1). Although early articulations of the evidential importance of records context and continuity were evident across a number of administrative and geographic environments, Muller et al. (2003) Handbook for Archival Administration is most often cited as the first set of formalized rules centering provenance as core archival principle. During the nineteenth and early twentieth century, provenance was first and foremost an ordering principle comprising two dimensions: respect des fonds, the aim of which was to ensure that records originating from the same creator or creating body remained together, and original order, which aimed to ensure that records were kept in the order imposed by their creator. Thus, from the outset, provenance has been oriented toward a twin concern for origins and order. Together respect des fonds and original order can be considered the external and internal expressions of provenance; the former is concerned with maintaining the whole of the records of a creator or creating body as a cohesive totality, and the latter is concerned with maintaining the relationships between records themselves (Horsman 1994; Douglas 2017). According to this understanding, provenance privileges a conceptualization of creatorship that is associated with the original record-generating body.

It is in this historical context that archivists themselves were positioned as neutral and non-interventionist (Cook 2013). However, as many archival practitioners and theorists have demonstrated, an archivist's ability to act as a neutral custodian in the interest of impartiality is easier said than done, and Muller, Feith, and Fruin's articulation of the fonds as the natural and organic accumulation of the records of a creator would be challenged as archivists and scholars recognized the impossibility of 
this construct (Barr 1987-1988). Concerned with the mutability of provenance, and its potential to account for a range of sociohistorical forces and contexts, a number of archival scholars have developed critical and alternative theories of archival creation, origins, and order in an attempt to rearticulate the concepts that have formed the basis for Western archival theory and practice since the late nineteenth century (Nordland 2004; Hurley 2005; Wurl 2005; Bastian 2006; Nesmith 2007; MacNeil 2008).

Building on the critical approaches to provenance and records creation that characterize the postmodern archival paradigm, Drake notes: "provenance emerged as a concept in the West at a time when most people were structurally if not legally excluded from ownership; ownership of their own bodies, minds, labor, property, and record. Its application in archives... reflects the limitation of state regimes in the West to recognize fully the human rights of indigenous Americans, black people, women, and gender non-conforming people" (2016). Further identifying how provenance works in the interest of dominant power structures, Wood et al. (2014, p. 401) suggest that archival arrangement and descriptive practices can "be read as a cumulative history of microaggressions." The authors note that provenance-informed descriptive standards "reveal a systemic and systematic picture of oppression against a multitude of disenfranchised, marginalized and oppressed groups who are involved in and/or affected by the creation and nature of the record" (2014, p. 402). Gracen Brilmyer's research extends Wood et al.'s critique, drawing attention to the erasure of disabled narratives that lie outside of stereotypical (and therefore partial) documentation such as medical or asylum records. Positioning the records of disability as always already fragmented, Brilmyer puts provenance's desire for a complete fonds, or a complete historical record, in conversation with disability studies' critique of curative and restorative frameworks. Brilmyer's work refigures the concept of provenance, positioning it as in a continual state of relational becoming (2020). Indeed, provenance's centering of singular, most-oftentimes white, male, exceptional creators demonstrates how provenance acts to valorize the privileged and the powerful while simultaneously obscuring the experiences and lives of those whose recordcreating activities strain against provenance's desire to contain the context of records creation to a singular creator body.

In previous writing on the history of feminized archival labor and the "handmaiden of history" trope, I've suggested that the archivist has historically performed reproductive labor that enables and protects a patrilineal provenance through the valorization of singular male creators (Lapp 2019). Geoffrey Yeo (2009) illustrates the provenancial contortions required to name and center singular creators using a sampling of personal records held in British archives. Yeo notes that the approach to naming and bounding a fonds around one individual-even if it is apparent that there were multiple creators at work in the creation of a body of records- "probably results from what might be called the 'Great Man' syndrome (and most of the named 'creators' were indeed men, even if it is questionable whether they were 'great')" further asserting "It seems to be widely assumed that the celebrity of a particular person, and a perceived need to give exclusive emphasis to this person's name in the title assigned to an aggregation, overrides any requirement to provide an unambiguous account of provenance" (2009, p. 57). Yeo's "Great Man Syndrome” illustrates 
how archival encounters with records have historically been shaped through provenance's concern with identifying and stabilizing a singular, patriarchal, context of creation. Drake elaborates, noting “....archivists often write massive memorials and monuments to wealthy, white, cisgender and heterosexual men... [that] serve to valorize and venerate white western masculinity" (2016).

Provenance's patrilineal valorization of singular, central, creators represented and manifested through respect des fonds and original order, reduce and simplify a record's origins to a single body, despite the fact that-with very few exceptionsrecords are shaped and formed by many different hands and forces. In archives of feminist materials where records are created, shaped, interpreted, re-shaped and recreated across wide and unprecedented contexts of access and use, containment to a discrete creator or creating contexts becomes an impossible, even laughable, task. Eric Ketelaar characterizes this range of creatorship as "activation." He suggests that "every interaction, intervention, interrogation, and interpretation of a record, by creator, user, and archivist is an activation of that record...All these activations are acts of co-creatorship that participate in determining the record's meaning" (2010, p. 203). Indeed, concepts of "co-creation" and "community creation" have been taken up by a number of other archival theorists working to problematize and provoke the nature of records creation (Hurley 2005; Bastian 2006; Iacovino 2010; Caswell 2014b; Douglas 2018). Taken together, these archival scholars demonstrate the distinct impossibility of containing a record's context to a singular record-creating body.

In her work exploring the photographic record of the Khmer Rouge regime, Michelle Caswell refuses archival language that would position Tuol Sleng prisoners as co-creators of their photographic prison record, suggesting that to do so would position victims of the Khmer Rouge as somehow complicit in their trauma, abuse, and murder (2014b). Likewise, Hurley proposes parallel provenance not as a way of neatly enumerating different acts of creation, but as a means of accounting for violent colonial acts alongside the experiences of Indigenous Australians living under a colonial program of forced removal, family dissolution, and cultural genocide (2005). As Caswell and Hurley demonstrate, not all record interventions can be reduced or elevated to the level of co-creation. Some acts are too big, too constituting, too forceful, too violent: photographing, classifying, enumerating, silencing. Some acts are too small, too imperceptible, too surreptitious: a smudge on a page, a sidewise glance towards the camera lens, the subtle re-ordering of files. In their work applying a feminist disability studies lens to archival descriptive practices, Brilmyer (2018) levies a similar critique, suggesting that an assemblage theory approach has the ability to account for, rather than flatten, the power relations that shape and constrain records (p. 111). Returning to Barad, we can consider intra-action as an alternative to the archival language of activation and co-creation. Intra-action allows for an understanding of records creation as distributed across many bodies, times, and encounters-big and small. It does not suggest that all acts of creation exert an equal creator-force on a record, instead, it positions records creation as a set of forces that come together in exchange to enact the world in very particular ways. When considering how a multitude of forces shape and constrain a body of records, intra-action accounts for ongoing and dynamic encounters between records, bodies, 
and knowledge; it lays the groundwork for conceptualizing and characterizing provenance as a set of unfolding and distributed relations. Provenancial Fabulation is a way of naming and exploring the intra-active nature of records creation in archives of feminist materials, of explicating how playful acts of records constitution, ordering, and contextualization are world-building.

\section{Provenancial fabulation}

Exploring provenancial fabulation further, we can position it as a feminist "revisioning" of provenance, one that "feels backwards" in order to build an intraactive understanding of records creation, attribution, and use (Rich 1979; Love 2007). Drawing from Saidiya Hartman's (2008) concept of "critical fabulation" and Donna Haraway's (2016) concept of "speculative fabulation," provenancial fabulation troubles linear characterizations of provenance by provoking and imagining records order and origins. In characterizing speculative fabulation as a strategy for contending with the world and our own ability to create meaning in it, Haraway writes: "it matters what matters we use to think other matters with; it matters what stories we tell to tell other stories with; it matters what knots knot knots, what thoughts think thoughts, what ties tie ties. It matters what stories make worlds, what worlds make stories" (2016, p. 12). Fabulation as a critical feminist practice and speculative undertaking aims to use supposition, storytelling, and imagination to build more inhabitable worlds; it has the ability to act infrastructurally to circulate feminist ideas and imaginaries (Toupin and Spideralex 2018).

Introduced by Hartman in her pivotal essay Venus in Two Acts (2008), critical fabulation is a mode of writing that strains against the archival record in order to tell as complete a story as possible. Elaborating on this approach Hartman states: "By playing with, and rearranging the basic elements of the story, by re-presenting the sequence of events in divergent stories and from contested points of view, I have attempted to jeopardize the status of the event, to displace the received or authorized account, and to imagine what might have happened or might have been said or might have been done" (p. 11). Critical fabulation challenges and reconfigures the temporal and spatial reach of the archive of Atlantic slavery; it is a powerful means of identifying and dismantling the hegemonic pull of the archive by writing in- and out-side of it at the same time. Critical fabulation pushes other ways of knowing into view, ways of knowing that labor against the imperial archiving project and its world-collapsing impetus to reduce the lives of enslaved women and girls to passing mention. While critical fabulation has been deployed as a writing practice to challenge the archival erasure of enslaved women and girls, provenancial fabulation is a practice of interrogating, challenging, and reconfiguring the archival systems that structure who and what matters enough to be made legible; it is a feminist tactic for re-envisioning, or re-visioning, records context, meaning and bonds. Adrienne Rich articulates "re-vision" as "the act of looking back, of seeing with fresh eyes, of entering an old text from a new critical direction-[it] is for women... an act of survival" (1979 p.35). Heather Love refers to this act of critical re-envisioning as "feeling backwards" (2007). In the archive, "feeling backwards" and "re-vision" are 
tactics for confronting the unknowability and uncontainability of feminist and queer archival bodies; as methods they speak to how certain bodies of archival records refuse the archival systems and processes that have historically reduced feminist and queer lives to footnotes, gaps, and annotated margins.

In feeling backward for queer histories, Love notes the necessity of fabulatory practices stating: "The inventiveness of a whole range of queer historical practices might be understood as a result of the paired necessities of having to 'fight for it' and to 'make it up' (2007 p. 130). Love speaks of a 'desired past-not a neutral chronicle of events but rather an object of speculation, fantasy and longing" (p. 130). The structuring role of archival imaginaries and imagined records as evidence and memory of that which is desired, anticipated, and yearned-for has also been theorized by archival scholars (Caswell 2014a; Caswell and Gilliland 2015; Gilliland and Caswell 2016; Brilmyer et al. 2019). Michelle Caswell suggests that "archivists are not just memory activists, but visionaries whose work reconceives imagined worlds through space and time" (2014a, p. 49). In centering how digital archival records can enable new modes of interrogating past assumptions, Caswell illustrates how archivists must "be inventive" and creative in their practices and methods in order to build new archival possibilities and potentials (p. 51). Although operating immaterially, the archival imaginary is a powerful source of evidence, memory, and community cohesion; it is a fabulatory practice of meaning making, anticipation, and speculation rooted in a desire for better evidence, better memories, and validation of lived and embodied experience.

Drawing from Hartman and Haraway's fabulatory practices, and the work of archival scholars in theorizing archival imaginaries, provenancial fabulation revisions records creation through the intra-action of archival forces and bodies. Provenance — both as context and as ordering principle - is that "matter we use to think other matters with" (Haraway 2016, p. 12). And how we figure records creation-the context of records origins and order-is paramount because every records configuration is able to shift, establish, and dismantle who and what matters enough to be made visible. In the remainder of this article, I will draw upon Alternative Toronto and Rise Up! to demonstrate the practice and potential of provenancial fabulation.

\section{Proposition one: provenancial fabulation plays with contradictory records contexts putting them in conversation with one another}

In discussing the tensions and challenges of archiving scenes she was actively part of, Alternative Toronto coordinator and lead Lilian Radovac reflects on how her own memories of 1990s activism in Toronto collide with, or challenge, the official historical narrative of that period as represented through news articles and city archival records. She notes that archiving her community's past "has served as a really interesting reminder, primarily through conversations with other people, that these events actually did have an impact and are still in the memories of people now. But you would never know that otherwise and that's been fascinating." Part of the work of Alternative Toronto as an archival formation has been to remember the past differently, to bring recollections and memories together to build more a holistic understanding of 
a moment in time-despite, or perhaps, in spite of-discrepancies between collective memory and more official historical accounts. In speaking of her archival practice, Radovac expresses that troubling and intervening in official histories-established through record keeping or through memory work - has the ability to put contradictory accounts in conversation with one another in a way that both validates and affirms her own experiences and memories. Beyond putting differing accounts of the past in dialogue, making decisions about how to structure record aggregations and categories has the ability to trouble feminist practice itself by acknowledging the wide ranging, and at time conflicting, spectrum of feminist thought and politics. Radovac states:

Feminist practice is interesting because it raises the question of what those practices mean in the context of communities whose feminism was formed at a very particular moment in time...That's been really interesting. So we're trying to keep things fluid in an effort to accommodate the widest possible range of values and practices without excluding anyone, while also having points where we go 'oh shit, what do we do when they come into conflict?' And sometimes, it's just learning how to just exist in that state of tension... which is not always easy.

Alternative Toronto's willingness to recognize the confluence of feminist ideas, attitudes and concerns beyond a generational rhetoric, while still acknowledging how feminism is understood and articulated by different people at different points in time, demonstrates how this archive has the ability to put contexts that may be "rife with contradiction" in dialogue with one another and transmit that uncertainty across space and time (Toupin and Spideralex 2018). It composes an important material-technological node in the feminist historical circuit that Withers (2015) characterizes as "feminism's-already-there". Withers notes that feminist generational thinking is a result of complex processes of transmission; narrative tropes are not value-neutral propositions, but rather practices that should be scrutinized (2015, p. 5). Provenancial fabulation is a mode of scrutinizing how information is transmitted and how it contributes to, or challenges, what we consider feminist knowledge. It allows for an interrogation of the values embedded in the processes of collective decision making, and the archival structures of representation that emerge from those collective values; it has to allow for a tension between values and viewpoints because feminist practice itself is fraught with contradictions. Radovac's articulation of the struggle to create a place where people with different experiences and understandings of feminist activism and feminist process can come together in exchange also speaks to the role of the archival interface as a site of imagination and speculation; it allows for meaning and memory to be transposed in myriad ways across time and space.

\section{Proposition two: provenancial fabulation troubles the order and organization of the past to imagine what "cannot be verified" or what could be}

Provenancial Fabulation disrupts easy chronologies and linear understandings of records creation, maintenance, and use. We can explore this insight by examining how feminist archiving projects extend historical struggle into contemporary movement organizing, and by acknowledging the stories, experiences, and narratives that 
come to the fore through this process. Both Alternative Toronto and Rise Up! have endeavored, either through online exhibitions or by circulating their archival content through social media and/or newsletters, to put the past in conversation with presentday concerns. Alternative Toronto, for instance, has developed an online "Days of Action" exhibit intended to demonstrate links between protests against the Harris Ontario Provincial government in the 1990s to protest actions against the 2019 Ford Ontario Provincial government, both of which instituted harsh austerity mandates and cuts to education and social services. ${ }^{3}$ The creation of explicitly political, social, cultural, and affective relations between various points in time and space and experience is an important feature of provenancial fabulation; it strains against provenance's reliance on singular creators and linear processes of records creation in an effort to characterize the reality of feminist organizing and struggle.

Writing on method (2019), Hartman proposes that "every historian of the multitude, the dispossessed, the subaltern, and the enslaved is forced to grapple with the power and authority of the archive and the limits it sets on what can be known, whose perspective matters, and who is endowed with the gravity and authority of historical actor" (p. xiii). Extending the practice of critical fabulation to include the process of “close narration," Hartman's Wayward Lives, Beautiful Experiments demonstrates how imaginative archival narration allows for the telling of speculative histories that don't exist otherwise. Hartman's use of close narration to characterize the lives and experiences of young Black women at the turn of the twentieth century reveals how storytelling can be both authorizing and destabilizing: it establishes presence while simultaneously pushing the archive off-kilter and challenging its discursive authority. The approaches to archival contextualization, arrangement, and description evident at Alternative Toronto and Rise Up! rely upon a similar commitment to authorization and destabilization. There is a desire to create connections across events, records, people, spaces, and times that defy the underlying logics of Western archival practice because building and maintaining those relations surfaces feminist struggle. The feminist archives seeks to both legitimate and disrupt.

Caswell, Ramirez, and Cifor's (2016) concept of representational belonging helps further explicate the drive to build new connections across records evident at Alternative Toronto and Rise Up! Referring to the important role communitybased archiving projects play in establishing presence, representational belonging "empower[s] people marginalized by mainstream media outlets and memory institutions with the autonomy and authority to establish, enact, and reflect on their presence in ways that are complex, meaningful, substantive, and positive to them in a variety of symbolic contexts" (2016, p. 57). Explicitly citing the work of Caswell, Ramirez, and Cifor, Lilian Radovac articulate her own archival practice with Alternative Toronto stating: "when Michelle Caswell et al. talk about "suddenly

\footnotetext{
3 Although outside the scope of this article, the Ford Ontario Provincial Government has most recently been under scrutiny for its poor handling of the COVID-19 crisis and for privileging profits over the health and safety of citizens. For more information see: Carter (2021) "Ontario health experts demand province abolish for-profit long-term care" and Angus Reid Institute (2021) "Ford Fumbles: Ontarians most likely to blame their provincial government for 'preventable' third wave".
} 
discovering yourself existing," I relate to that strongly. I think a lot of people do." The reality of feminist organizing from the 1970s to 1990s was that much went unarchived and un-preserved. As Meg Luxton-a member of the Rise Up! organizing collective-suggests during a group interview, people were moving around, materials were discarded or lost, and much of the organizing work was not the sort that generated textual evidence in the first place. Recognizing the power of seeing yourself in history, Radovac states: "It's...been amazing to be able to provide acknowledgement of some of the people who have been under-represented, and to witness what it means when women and non-binary folk and particularly when people who come from working class and poverty class backgrounds see they have an opportunity to be remembered" (Caswell 2014c). These digital archives with their carefully structured and arranged bodies of records are attempting to re-order and re-organize the past through imagining that which "cannot be verified," for instance, the experiences and lives of poverty-class and working-class folks in Toronto (Hartman 2008, p. 13). In constituting bodies of records that establish "presence in archives in complex, meaningful, and substantive ways," provenancial fabulation connects the past, the present, the political, and the personal. As a system of attribution, it elaborates archival creation across myriad sites and actors in the service of building feminist knowledges and narratives.

\section{Proposition three: provenancial fabulation extends the temporal and spatial boundaries of historical records and accounts}

This dimension of provenancial fabulation speaks directly to how both Alternative Toronto and Rise Up! have approached aggregating and grouping their holdings. First, the act of archival reification, the very process of rendering materials digital and compiling them into interpretable aggregates, interferes with the temporal and spatial parameters of the original record. The original record is afforded a new and unpredictable trajectory in time and space by virtue of being rendered both digital and archival. Second, the aggregative groupings of the records put them into new proximities, new material-semiotic formations, that are not necessarily oriented towards any shared relationship to place, time, or creator. Reflecting on the archive's ability to extend temporal and spatial boundaries, Tara Cleveland of Rise Up! states: "For me as a younger woman, that's what's so important about doing this work now...fifty years from now, when a lot of people might say 'oh yeah that's definitely history' it's too late to get all those connections. It's too late to get that lived experience and that knowledge." Cleveland's articulation of the integral role of the archive in establishing feminist narratives as both useful and transportable across different milieus is an important dimension of provenancial fabulation.

Provenancial fabulation's imperative to trouble and extend how records are affirmed and re-affirmed archivally as they enter into new spatial and temporal configurations requires a revisiting of the archival bond. Positioned as "the network of relationships that each record has with the records belonging in the same aggregation" (Duranti 1997, p. 216), the archival bond is a central means of understanding how archival fonds are structured-it refers to the relationships between records 
emerging out of a shared context of use. Expanding on the centrality of the archival bond, MacNeil (2008) suggests that "a body of records is shaped not only by its archival bond but, also, by what we might term a custodial bond, meaning the relations that exist between a body of records and the various custodial authorities that interact with the records over time, including archivists and archival institutions" (p. 14). Characterizing the custodial bond through the concept of "archivalterity" MacNeil states: "archivalterity refers to the acts of continuous and discontinuous change that transform the meaning and authenticity of a fonds as it is transmitted over time and space" (p. 14). Aggregated around subject matter, form, and/or donor affiliation, records held by Alternative Toronto and Rise Up! extend our understanding of the archival bond. As records are categorized, grouped and re-grouped through keyword search, or collective decision making - the archival bond itself becomes destabilized. In digital archives, and certainly in the specific examples discussed here, the custodial bond - the act of archivalterity — of continuous and discontinuous change-becomes a significant means of understanding record aggregates. In digital archives of feminist materials the intervention of myriad record shaping forcesmembers of the archival collectives, users of the interface, algorithmic programming-influence how a body of records will be transmitted and transported across time and space. Driven by an imperative to build interpretable narratives of feminist struggle, provenancial fabulation plays with, disturbs, and provokes the bonds between records, intervenors, and contexts.

\section{Proposition four: provenancial fabulation acts infrastructurally to circulate ideas, imaginaries, narratives, and relationalities}

Sophie Toupin and Spideralex suggest that speculative methods and practices "[are] infrastructural as [they allow] for the circulation of ideas, fabulations and dreams among others" (2018). Indeed, feminist archives have long acted infrastructurally to generate and circulate knowledges (Eichhorn 2014a; Cifor and Wood 2017; Moravec 2017; McKinney 2020). The digital archives I discuss here are small pieces in the feminist project of world building, distinct nodes in Withers' aforementioned "feminisms-already-there" transmissive circuit. The transmission of feminism'salready-there "can be a very modest encounter, occurring between one person and a feminist book, film or song, or it can aim to involve significant numbers of people through an exhibition or digital archive" (Withers 2015, p. 5). Provenancial fabulation can be positioned as an important structuring force in the transmission of feminist imaginaries. It makes that moment of encounter-between people and archival information and knowledge-possible, or conversely, impossible. Its infrastructural force has the ability to build, maintain and perpetuate contexts, origins and histories. Provenancial fabulation, while enabling the creation and circulation of feminist imaginaries, also refigures concepts of authorial voice and intellectual ownership, giving voice to, and silencing, certain acts of records creation.

In the context of Rise Up! Tara Cleveland notes that for most of the archival materials in the collective's care, no authors are credited, and even in cases where they are, much of the original inscription work was done by a group of people. She 
further observes that even if there were copyright agreements in place, those rights did not include rights to digital publication, since it was not even a remote concern in the 1970s and 1980s. Further complicating the process of attribution, many of the publications at Rise Up! appropriated graphics and illustrations from other publications, remixing them into new genres and material contexts. In contending with this reality Cleveland states: "So do we decide we're going to lose this history in order to figure out the copyright? Basically what we decided was, no, this is important to preserve." Reflecting on Rise Up!'s approach to digital publication which is built around public access, and backed by a take-down policy and the fair dealing provision of Canadian copyright law, Cleveland says "the way that copyright laws work, doesn't really capture how a movement works."

Describing how the Rise Up! collective has figured digital publication and access Cleveland notes: "It's definitely a different way of looking at these materials than a lot of traditional archives have. And I think it is... a more feminist, people-centered vision of material that people produced. It's great when we can find the person who's responsible for it, but often there isn't one person, or the organization doesn't exist, or people are all disappeared." Rise Up! and Alternative Toronto both demonstrate approaches to public access that figure records attribution beyond a legalistic-rights based framework, instead orienting their approach towards a feminist ethics of responsibility and collective ownership (Caswell and Cifor 2016; Radovac 2017; Cowan and Rault 2018). For the Rise Up! collective, making materials available online for use and circulation in the present is an act of care; it represents an acknowledgement that the work of past feminist organizers was important and worthy of circulation despite legalistic imperatives not to make the materials available. In making decisions to publicize, Rise Up! has taken the position that copyright law is ill equipped to manage movement materials, and as a result, the collective has created its own internal framework of circulation and attribution based on a collective understanding of who should own and control feminist movement materials.

The practice of provenancial fabulation requires figuring and imagining who should or does own feminist knowledge and building the conditions of possibility for that knowledge to circulate. Like all ethical practices, it is highly situated and embedded, there is no one correct way to digitize the feminist past; certainly many convincing arguments have been made for not digitizing trans feminist and queer materials (Eichhorn 2014b; Moravec 2017; Cowan and Rault 2018). Even the shared concern that digital publication should be people-first is interpreted differently across different sites. At Rise Up! people-first has translated to a framework of collective ownership and control, and at Alternative Toronto it is enacted through the highly individuated practice of allowing each contributor to make their own decisions about access; donors have the opportunity to decide if they want creative commons licensing applied to their donated materials, and furthermore, what the terms of the license should be. It is often tempting to speak about feminism's archive as a discursive structure, one that embodies all of feminism's knowledges, contradictions, and feelings, one that can be tapped into upon any number of different encounters. However, when I talk about provenancial fabulation as operating infrastructurally to circulate ideas, narratives, and stories, I am also referring to the concrete and tangible conditions of public and private circulation which are shaped 
and constrained by how archival authorship, control, privacy, and ownership are structured. At Alternative Toronto and Rise Up! it is a structuring formed through highly situated and embedded understandings of origins and context. Provenancial fabulation is an infrastructure of desire, possibility, and longing for better narratives and better stories, but it is also an infrastructure of control, management, and care that does the transmissive work of building feminist life worlds.

\section{Conclusion}

Rise Up! member Tara Cleveland's assertion referenced at the outset of this article- "we approached everything from a feminist perspective because that's the only way we knew how to do it"-articulates the values, systems, and approaches that inform provenancial fabulation as a feminist figuring of records order and origins that disrupts the "power and patriarchy" of archival provenance (Drake 2016). By decentering the notion of a singular, remarkable creator in favor of a multiplicity of intra-acting contexts and actors, Rise Up! and Alternative Toronto enable imaginative acts of records creation that play with the spatial and temporal boundaries of records, pushing them into new, oftentimes unanticipated relationships to other records, users, and intervenors. Throughout this article I have proposed that provenancial fabulation can be characterized through four dimensions: first, it plays with contradictory record contexts putting them in conversation with one another; second, it troubles the order and organization of the past; third, it extends the temporal and spatial boundaries of historical records and accounts; and fourth, it acts infrastructurally to circulate ideas, imaginaries, narratives, and relationalities. In creating and configuring digital records according to feminist understandings of archival value and historical continuity, Alternative Toronto and Rise Up! demonstrate provenancial fabulation as a structuring force in the circulation of feminist knowledges and desires.

As feminist archival thought and practice move the field beyond discussions of how women are represented in archives and towards the power of feminist discourse to dismantle and confront "the heteronormative, racist, patriarchy on many fronts and through many avenues" (Cifor and Wood 2017, p. 2), feminist methodologies and epistemologies are a powerful means of addressing the tenets of Western archival scholarship and practice. Twenty years ago, Terry Cook made the assertation that archival concepts are never fixed or universal, but rather, that they are "historically contingent" (2001, p. 27). The concept of provenancial fabulation plays with the agility of provenance, records creation, origins, and order, reworking them through feminist frameworks in order that they are better able to commit to a feminist understanding of futurity and possibility, one that demands we are careful in our archival practice, and that we act responsibly and reciprocally toward the many people whose lives are imbricated in record-making and record-keeping in all forms. Provenancial fabulation, as a feminist practice of records attribution and contextualization, is not being presented as a solution to provenance's constraints and limitations, rather, it is being forwarded as a critical praxis that has emerged out of the feminist and queer imperative to "fight for it" and "make it up" (Love 2007 p. 
130). In writing a different story - a speculative story-about the lives of enslaved girls and women, Hartman uses critical fabulation to shift the vantage point, to move elements of the story around to force an unyielding archive to relent to fabulation, desire, and imagination (2008). Provenancial fabulation requires a similar commitment to inventiveness and desire, a willingness to re-structure (or un-structure) records creation, attribution, and context, to push other ways of knowing into view, not merely because it's possible, but because it's necessary for building the conditions for feminist knowledge to circulate, shift, and change.

Lola Olufemi (2020) writes "feminism is a political project about what could be. It's always looking forward, invested in futures we can't quite grasp yet. It's a way of wishing, hoping, aiming at everything that has been deemed impossible" (p. 1). The approaches to attributing and contextualizing digital records that I detail here demonstrate feminism's endless commitment to possibility, speculation, justice, and political transformation. And this is what provenancial fabulation ultimately proposes: it invites a grammar of records order and origins that aligns with feminist understanding of knowledge generation, circulation, stewardship, and use. It is a revisioning of provenance that pushes it to account for all we dream possible.

Acknowledgements Thank you to my ICHORA panel co-participants Gracen Brilmyer and Ayantu Tibeso for their insights and the opportunity to present this work for the first time. I also want to acknowledge Gracen Brilmyer and Calev Litvack for their thoughtful editorial comments and critiques throughout the writing process; this article is the stronger for it. I am very grateful to Lilian Radovac of Alternative Toronto and Tara Cleveland of the Rise Up! organizing collective for their willingness to participate in this project and for trusting me with their stories. This article is an abbreviated and adapted version of the third chapter of my doctoral dissertation, "The Provenance of Protest: Conceptualizing Records Creation in Archives of Feminist Materials" (PhD diss., University of Toronto, 2020), and I am endlessly thankful to Heather MacNeil for reading and re-reading drafts of this work. Finally, I would like to thank the anonymous peer reviewers whose comments strengthened and sharpened this work. This research was made possible thanks to the financial support of the Social Sciences and Humanities Research Council of Canada (SSHRC), and the Faculty of Information at the University of Toronto.

\section{References}

Angus Reid Institute (2021) Ford Fumbles: Ontarians most likely to blame their provincial government for "preventable" third wave. Angus Reid Institute, https://angusreid.org/ford-ontario-covid/

Barad K (2007) Meeting the universe halfway. Duke University Press, Durham

Barad K (2014) Diffracting diffraction: cutting together -Apart. Parallax 20(3):168-187

Barr D (1987) The fonds concept in the working group on archival descriptive standards report. Archivaria 25:163-170

Bastian J (2006) Reading colonial records through an archival lens: the provenance of place, space and creation. Arch Sci 6:267-284

Brilmyer G (2018) Archival assemblages: applying disability studies' political/relational model to archival description. Arch Sci 18:95-118

Brilmyer G (2020) Proximity matters: disability, erasure \& the archival bond of natural history (Doctoral Dissertation). University of California Los Angeles

Brilmyer G, Gabiola J, Zavala J, Caswell M (2019) Reciprocal archival imaginaries: the shifting boundaries of "community" in community archives. Archivaria 88:6-48

Browne S (2015) Dark matters: on the surveillance of blackness. Duke University Press, Durham

Butler J (1997) Excitable speech. Routledge, New York 
Calderon-Sandoval O, Sanchez-Espinosa A (2019) Feminist documentary cinema as a diffraction apparatus: a diffractive reading of the Spanish films, Cuidado, resbala and Yes, We Fuck!. Soc Sci 8:1-14

Carter A (2021) Ontario health experts demand province abolish for-profit long-term care. CBC https://www.cbc.ca/news/canada/toronto/ontario-long-term-care-1.5888226

Caswell M (2014) Inventing new archival imaginaries: theoretical foundations for identity-based community archives. In: Daniel D, Levi A (eds) Identity palimpsests: archiving ethnicity in the U.S. and Canada. Library Juice Press, Sacramento, pp 35-55

Caswell M (2014b) Archiving the unspeakable. University of Wisconsin Press, Madison

Caswell M (2014c) Seeing yourself in history: community archives and the fight against symbolic annihilation. Public Hist 36(4):26-37

Caswell M (2019) Dusting for fingerprints: introducing feminist standpoint appraisal. J Crit Libr Inf Stud 3(1):1-36

Caswell M, Cifor M (2016) From human rights to feminist ethics: radical empathy in the archives. Archivaria 81:23-43

Caswell M, Cifor M, Ramirez MH (2016) 'To suddenly discover yourself existing': uncovering the impact of community archives. Am Arch 79(1):56-81

Caswell M, Gilliland A (2015) False promise and new hope: dead perpetrators, imagined documents and emergent archival evidence. Int J Hum Rights 19(5):615-627

Cifor M, Wood S (2017) Critical feminism in the archives. J Crit Libr Inf Stud 1(2):1-27

Clover DE, Williamson S (2019) The feminist museum hack as an aesthetic practice of possibility. Eur J Res Educ Learning Adults 10(2):143-159

Cook T (2001) Archival science and postmodernism: new formulations for old concepts. Arch Sci 44:3-24

Cook T (2013) Evidence, memory, identity, and community: four shifting archival paradigms. Arch Sci 13(2-3):95-120

Cowan TL, Rault J (2018) Onlining queer acts: digital research ethics and caring for risky archives. Women Perform 28(2):121-142

Douglas J (2017) Origins and beyond: the ongoing evolution of archival ideas about provenance. In: MacNeil H, Eastwood T (eds) Currents of archival thinking, 2nd edn. Libraries Unlimited, Santa Barbara, pp 25-53

Douglas J (2018) A call to rethink archival creation: exploring types of creation in personal archives. Arch Sci 18(1):29-49

Drake J M (2016) RadTech meets RadArch: towards a new principle for archives and archival description. Medium. https://medium.com/on-archivy/radtech-meets-radarch-towards-a-new-principlefor-archives-and-archival-description-568f133e4325. Accessed 23 Aug 2021

Duranti L (1997) The archival bond. Arch Mus Inform 11:213-218

Eastwood T (1994) What is archival theory and why is it important? Archivaria 37:122-130

Eichhorn K (2014a) The archival turn in feminism: outrage in order. Temple University Press, Philadelphia

Eichhorn K (2014b) Beyond digitisation: a case study of three contemporary feminist collections. Arch Manuscr 42(3):227-237

Gilliland A, Caswell M (2016) Records and their imaginaries: imagining the impossible, making possible the imagined. Arch Sci 16:53-75

Haraway D (1988) Situated knowledges: the science question in feminism and the privilege of partial perspective. Fem Stud 14(3):575-599

Haraway D (1992) The promises of monsters: a regenerative politics for inappropriate/d others. In: Grossberg L, Nelson C, Treichler P (eds) Cultural studies. Routledge, New York, pp 295-337

Haraway D (2016) Staying with the trouble: making kin in the Chthulucene. Duke University Press, Durham

Hartman S (2008) Venus in two acts. Small Axe 12(2):1-14

Hartman S (2019) Wayward lives, beautiful experiments intimate histories of social upheaval. VW Norton \& Co, New York

Harris V (2002) The archival sliver: power, memory, and archives in South Africa. Arch Sci 2:63-86

Hooks B (1989) Choosing the margin as space of radical openness. Framew J Cine Media 36:15-23

Horsman P (1994) Taming the elephant: an orthodox approach to the principle of provenance. In: Abukhanfusa K, Sydbeck J (eds) The principle of provenance: report from the stockholm conference on archival theory and the principle of provenance. Swedish National Archives, Sweden, pp 51-63 
Hurley C (2005) Parallel provenance: when something is not related to everything else. Arch Manuscr 33(2):52-91

Iacovino L (2010) Rethinking archival, ethical and legal frameworks for records of indigenous Australian communities: a participant relationship model of rights and responsibilities. Arch Sci 10:353-272

Ketelaar E (2010) Records out and archives early modern cities as creators of records and as communities of archives. Arch Sci 10:201-210

Lapp JM (2019) 'Handmaidens of history:' speculating on the feminization of archival work. Arch Sci 19(3):215-234

Love H (2007) Feeling backward: loss and the politics of queer history. Harvard University Press, Cambridge

MacNeil H (2008) Archivalterity: rethinking original order. Archivaria 66:1-24

McKinney C (2020) Information activism: a queer history of lesbian media technologies. Duke University Press, Durham

Moravec M (2017) Feminist research practices and digital archives. Aust Fem Stud 32(91-92):186-201

Muller S, Feith JA, Fruin R (2003) Manual for the arrangement and description of archive (A.H. Leavitt, Trans.), 2nd edn. Society of American Archivists, Chicago

Nesmith T (2007) The concept of societal provenance and records of nineteenth-century AboriginalEuropean relations in Western Canada: implications for archival theory and practice. Arch Sci 6:351-360

Nordland L (2004) The concept of 'secondary provenance': re-interpreting Ac ko mok ki's map as evolving text. Archivaria 58:147-159

Olufemi L (2020) Feminism, interrupted: disrupting power. Pluto Press, London

Radovac L (N.D.) About. Alternative Toronto. https://www.alternativetoronto.ca/archive/about Accessed 23 August 2021

Radovac L (2018) Re/mediating the archive: building alternative Toronto. Continuum J Med Cult Stud 32(1):97-110

Rich A (1979) On lies, secrets, and silence: selected prose 1966-1978. W.W. Norton \& Company Inc, New York

Rise Up! (N.D.) About Rise Up Feminist Archive. Rise Up! Feminist Archive. https://riseupfeminista rchive.ca/about-rise-up-feminist-archive Accessed 23 August 232021

Toupin S (2018) Introduction: radical feminist storytelling and speculative fiction: creating new worlds by re-imagining hacking. ADA J Gender New Media Technol. https://doi.org/10.5399/uo/ada.2018. 13.1

Withers D (2015) Feminism, digital culture and the politics of transmission: theory practice and cultural heritage. Rowman \& Littlefield International, London

Wood S, Carbone K, Cifor M, Gilliland A, Punzalan R (2014) Mobilizing records: re-framing archival description to support human rights. Arch Sci 14:397-419

Wurl J (2005) Ethnicity as provenance: in search of values and principles for documenting the immigrant experience. Arch Issues 29(1):65-76

Yeo G (2009) Custodial history, provenance, and the description of personal records. Libr Cult Rec 44(1):50-64

Publisher's Note Springer Nature remains neutral with regard to jurisdictional claims in published maps and institutional affiliations.

Jessica M. Lapp completed her PhD in archival studies at the University of Toronto's Faculty of Information in 2020. Her research focuses on feminist archival practice and process, records creation, provenance theory, and the creation, maintenance, and use of digital surrogate records. Her work has been published in Archival Science, Australian Feminist Studies and Information \& Culture. 